\title{
“RESSONÂNCIAS ANTIGAS”: PREGÕES DE RUA EM BAÚ DE OSSOS
}

\author{
"ANCIENT RESONANCES": STREET CRIES IN BAÚ DE OSSOS
}

Maria Alice Ribeiro Gabriel ${ }^{1}$

\begin{abstract}
RESUMO: A historiografia cultural e a história literária podem fazer da escrita memorialística fonte de saber? Segundo uma perspectiva histórica e literária, este estudo visa explorar a questão dos vendedores de rua em Baú de Ossos (1972), primeiro volume das Memórias de Pedro Nava. O objetivo é analisar o pregão e a imagem dos vendedores ambulantes entendidos no sentido de objeto cultural no espaço social da cidade do Rio de Janeiro, entre os séculos XIX e XX. No quadro deste estudo constam reflexões de Pierre Nora (1989), Jean-Yves Boursier (2002), José Ramos Tinhorão (2005) e Emmanuel Diet (2010). O pregão e os vendedores ambulantes figuram no discurso literário de Nava de modo historicizado, claro e vivo, mas sob estética única e perspectiva (auto)biográfica.

Palavras-chave: Pedro Nava; memórias; objeto cultural, patrimônio cultural, pregão.
\end{abstract}

Résumé: L'historiographie culturelle et l'histoire littéraire peuvent-elles faire de l'écriture memorialistique une source de savoir? Selon une perspective historique et littéraire, cette étude vise explorer la question de les vendeurs de rue dans Baú de Ossos (1972), premier volume des Mémoires de Pedro Nava. L'objectif est analyser le prégon et l'image des vendeurs ambulants entendus au sens de objets culturelles, dans l'espace social de la ville de Rio de Janeiro, entre le XIX et XX siècle. Dans le cadre de cette étude sont présents les réflexions de Pierre Nora (1989), Jean-Yves Boursier (2002), José Ramos Tinhorão (2005) et Emmanuel Diet (2010). Le prégon et les vendeurs ambulants sont représentés dans le discours littéraire de Nava de maniére historicisée, claire et vive, mais avec une esthétique unique, et une perspective (auto)biographique.

Mots-clé: Pedro Nava; mémoires; objet culturel; patrimoine culturel, pregón.

\section{Introdução}

Pedro Nava apreendeu a memória individual e coletiva em mais de um domínio das Memórias, entremeando os planos biográfico e autobiográfico com breves tratados sobre o caráter associativo e voluntário das operações mnemônicas, sobre a percepção sensorial como "viagem no tempo" e estímulo criativo para as "analogias e transposições poéticas".

As relações entre memória e história na sua obra oferecem vasto campo de pesquisa, considerando a extensão do arquivo pessoal e familiar do autor, depositado na Fundação Casa de Rui Barbosa. Além de comportar o arquivo do escritor cearense Antônio Salles, o acervo de Pedro Nava subdivide-se em seções documentais que conduzem à história de outras famílias: "Por certo servirão de exemplo os dossiês dos Nava, dos Halfelds, dos Penido, dos Pamplonas,

\footnotetext{
${ }^{1}$ Doutora em História Social pela Universidade de São Paulo-USP. Pesquisadora vinculada ao Laboratório de Estudos Judaicos da Universidade Federal de Uberlândia-UFU.
} 
dos Alencares, para citar alguns”, conforme observado por Eliane Vasconcelos (2001, p. 30). O estudo dos fundamentos da obra naveana revela o trabalho de arquivamento, coleta, pesquisa e seleção de fontes e documentos, feito por um cultor dedicado, erudito e paciente da memória e de suas representações históricas e literárias.

No ensaio "Poesia e ficção na autobiografia", Antonio Candido (1989) distinguiu a presença de elementos ficcionais e poéticos nos escritos (auto)biográficos de Pedro Nava, notadamente nos primeiros volumes das Memórias, Baú de Ossos (1972) e Balão Cativo (1973). Antonio Candido (1989, p. 55) analisou alguns recursos estilísticos e estratégias narrativas que permitem ao texto naveano ser lido "como se fosse ficção", considerando-se a perspectiva do "Narrador" como "a voz que se lançou A procura do tempo perdido".

Em La Mémoire, l'Histoire, l'Oubli (2000, p. 511), sob enfoque duplo, filosófico e historiográfico, Paul Ricoeur definiu a atividade analítica de perscrutar o passado, ao qual o homem se relacionaria de modo "incompleto e obscuro", em face do "l'énigme d'une représentation présente du passé absent”. Sondando a memória, por vezes a partir de uma fonte comum, o poeta, o ficcionista e o historiador lançam mão de instrumentos diversos para reconstituir o passado, buscando deste a imagem ideal. Assim, a representação de um mesmo objeto encerra efeitos de sentido originais, como na série daquelas pinturas de Claude Monet, feitas em 1890, expondo a fachada da Catedral de Notre-Dame de Rouen. A passagem do tempo projeta matizes de cores, sombra e luz sobre uma figura unívoca, cuja contemplação se modifica, conforme a catedral é retratada em dias e horas diferentes.

Pedro Nava exercita-se com fluência na prosa ensaística, na crônica histórica e de costumes. A imagem da catedral ilustra o estilo da linguagem que o memorialista adota em certas passagens. Nesta, ele descreve o sobrado familiar dos Nava no Rio Comprido, Rio de Janeiro, “em Aristides Lobo, 106”, durante a primeira década do século XX:

A noite mudava completamente a fachada de nossa casa, a paisagem da rua. Desmaiavam certas saliências, outras massas avultavam, como naqueles quarenta quadros em que Claude Monet pintou quarenta fachadas da Catedral de Rouen, cada uma diversa, na luz dum minuto diferente. Como nas telas impressionistas, nossa rua, conforme a hora, mostrava casas que duma dureza de granito ao sol do meio-dia, viravam numa espuma de ouro à luz da tarde e por fim se esvaíam - evaporadas na bruma noturna. (NAVA, 1974, p. 334-335, grifo do autor).

A fim de especificar o objeto de estudo deste artigo, o pregão do vendedor de rua, é necessário delimitar sua inscrição no plano biográfico de Baú de Ossos, ressaltando um aspecto comum ao "veio autobiográfico sem amargura" da poética de Carlos Drummond de Andrade em alguns poemas de Boitempo (1968) e Boitempo II - Menino antigo (1973):

A experiência pessoal se confunde com a observação do mundo e a autobiografia se torna heterobiografia, história simultânea dos outros e da sociedade; sem sacrificar o cunho individual, filtro de tudo, o Narrador poético dá existência ao mundo de Minas no começo do século. (CANDIDO, 1989, p. 56). 
Robert Vosloo (2017, p. 38) fez a seguinte relação entre memória pessoal e o que Candido denominou "história simultânea dos outros e da sociedade": memória e história apontam para duas distintas e interconectadas rotas epistemológicas de conhecimento do passado. De um modo mais direto, a história baseia-se em fontes empíricas, nas quais a memória é moldada por relatos (que são "histórias") do passado. De maneira análoga, a memória apoia-se em testemunhas oculares e nos seus depoimentos (que são lembranças). A despeito das equivalências e conexões, o mundo da memória mostra-se muito diverso do mundo da história. O memorialista dispõe de uma terceira "rota" para reconstituir o passado, por uma rede de associações entre desejo, emoção, imaginação e esquecimento.

Ajustando essas três "rotas" aos planos biográfico e autobiográfico, a reconstituição do passado nas Memórias apreende diversos objetos culturais da história do cotidiano. De acordo com o crítico musical José Ramos Tinhorão (2005, p. 59): "De todas as manifestações musicais do povo das cidades o pregão continua até hoje como das menos estudadas e documentadas, quer na parte da música, quer nas letras”. Apoiando-se nessa assertiva, o propósito deste artigo é analisar as referências aos pregões e ambulantes em Baú de Ossos, com o objetivo de distingui-los no texto naveano como objetos culturais.

\section{Pregões, vendedores ambulantes e a questão do objeto cultural}

Ao definir o pregão da perspectiva do folclorista, Mário Souto Maior evocou os pregões antigos do Recife circunscrevendo-os ao espaço da memória e do trabalho. A venda de artefatos e de toda sorte de alimentos e frutos da região por meio de cantos, interpelações e récitas alude ao tempo em que predominavam ofícios manuais, em contraste com os pregões acompanhados de sons ligados à experiência de mecanização de atividades que antes eram de caráter artesanal. Patrimônio imaterial que pode ser construído, transmitido e disperso na teia do trabalho usualmente informal, o pregão remete à circulação de saberes e ocupações profissionais já extintos, por conseguinte:

Os pregões são outra manifestação folclórica de muita beleza. Cantados, falados, ou tocados, cada cidade tem os seus pregões. E o Recife, como não poderia deixar de ser, também tem os seus. Entre os pregões antigos temos o do vendedor de pitomba: "- Ei, piripiripiripiripitomba! Menino chora prá comprar pitomba! Ei, pitomba!" Outros pregões enchem de melodia a vida e a saudade de muita gente: “- Olhe o rolete! Rolete é de cana caiana! Quem vai querer?”; “- Eu tenho lã de barriguda prá travesseiro!” “- Ostra chegada agora! Chegada agora... Chegada agora...”; “- Mé novo, de engenho!”; (...) “Macaxeira! Macaxeira Bahia, cozinha n'água fria!” E o vassoureiro? Quem, com mais de trinta anos de idade não se lembra da figura folclórica do vassoureiro, com seus dois balaios pendentes de um pedaço de caibro sobre os ombros, balaios cheios das mercadorias constantes de seu pregão melodioso: "- Vassoura, abano, espanador, bacia de lavar prato, regador, colher de pau, esteira d'Angola, rapa-coco, grelha! Olha o vassoureiro! Vai querer hoje?" E estes outros, também bonitos e saudosos, como: “- Doce gelado!" “- Sorvete! É de coco e de maracujá!” É bom explicar que doce gelado era como se denominava o picolé de hoje, logo quando apareceu. Era redondo e não tinha o formato dos picolés de agora. Os pregões atuais, quase todos, com exceção 
de alguns, são tocados como a trombeta do vendedor de picolé, a sineta do pipoqueiro, a gaitinha do vendedor de cuscuz e do amolador de tesouras, a sineta do caminhão de gás, etc. Entre as exceções, lembro: “- Olha o amendoim! Amendoim torradinho! “- Caranguejo! Olha o carangueijo!” (...) “- Cavala! Olha a cioba! (MAIOR, s/d).

Conforme observado por Luiz Carlos Soares (2007), a literatura de viagem oferece valioso registro das atividades dos vendedores ambulantes no Brasil colonial. $\mathrm{O}$ comércio de miudezas abastecia a capital do Império, povoações e vilas do interior, principalmente pelas mãos dos chamados escravos de ganho, cujo trabalho tinha início logo nas primeiras horas do dia. Soares conecta o pregão à música na "situação de cativeiro", evidenciando a questão da memória cultural do ambulante escravo, entoando seus "cantos africanos":

Durante a maior parte do dia, os trabalhadores escravos enchiam as ruas do Rio de Janeiro com seus cantos africanos, seus pregões anunciando a excelência de suas mercadorias, seu falatório e sua aparente alegria, recursos estes que os encorajavam no trabalho e os ajudavam a suportar a situação de cativeiro. Esta multidão de escravos nas ruas foi vista pelos visitantes estrangeiros através de muitos e diferentes olhares. (SOARES, 2007, p. 87).

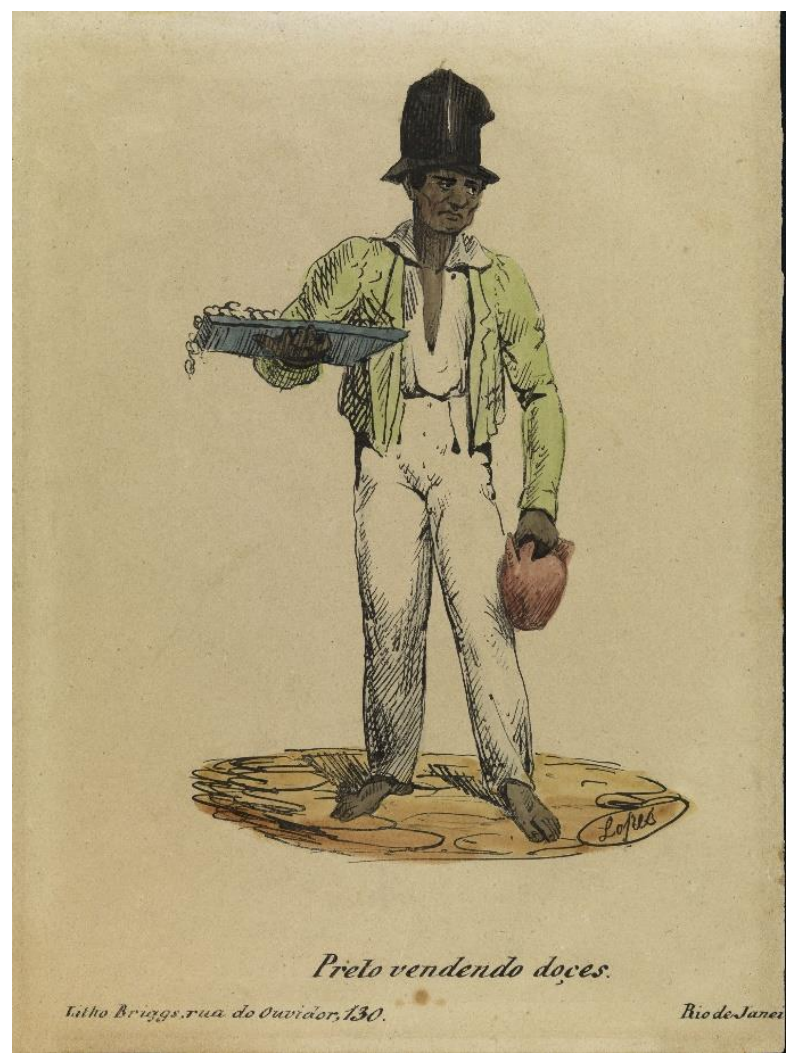

Figura 1 - Preto vendendo doces, Rio de Janeiro, c. 1840.

Retirada de: BARROS, Joaquim Lopes de. Slave Trade. Biblioteca Nacional.

Disponivel em:

<http://bndigital.bn.gov.br/projetos/escravos/galeriagravuras.html/>

Acesso em: 15 de out. de 2019.

Machado de Assis (1978, p. 201) correlacionou as memórias pessoal e coletiva quando Bentinho recorda, nostálgico: [...] o pregão que o preto foi cantando, o pregão das velhas tardes, 
tão sabido do bairro e da nossa infância: Chora, menina, chora, / Chora, porque não tem/ Vintém”. Utilizando uma expressão de Pedro Nava (1974, p. 303), é possível considerar a canção do "preto das cocadas de Mata-cavalos", em Dom Casmurro (1899), uma "[...] das chaves da memória que serviram ao nosso Machado, a Gérard de Nerval, a Chateaubriand, a Baudelaire, a Proust”. As considerações de Pedro Nava sobre as memórias voluntária e associativa privilegiam o papel da imaginação e do inconsciente.

A noção de objeto cultural proposta por Emmanuel Diet (2010, p. 40) denota certo viés proustiano ao compreender todo objeto psíquico ou material como motor de cenários fantasmáticos, dinâmicas pulsionais, onirismos, associações entre discurso, significante, representação, esquema de pensamento, ideia, ideal, obra, artefatos e técnicas relativas a determinado contexto sócio-histórico. Diet atribui aos objetos culturais a função de atuar como vetores mnemônicos no plano intersubjetivo e intrapsíquico, o que justificaria, em parte, o aporte sugestivo da entoação, ritmo e melodia dos cantos e dizeres dos pregões.

O interesse de Mário de Andrade em registrar melodia e verso dos pregões resultou no Ensaio sobre a música brasileira, estudo publicado em 1928, contendo exemplos e variações de peças folclóricas de origem diversa, expressas em forma musical ou recitativa (aboio, acalanto, coco, desafio, embolada, fandango, lundu, martelo, modinha, pregão e toada) de estilos conectados a diferentes culturas e que são o compósito de intrincado sistema de influências:

Dentre os desafios muitos se revestem duma forma estrófica tão vaga (...) que são recitativos legítimos. Ainda sob o ponto-de-vista da melodia infinita os fandangos paulistas são de modelo bom. E ainda lembro os martelos, certos lundus muito africanizados (...) as parlendas, os pregões os cantos-de-trabalho sem forma estrófica, as rezas das macumbas. Todas essas formas se utilizando de motivos rítmico-melódicos estratificados e circulatórios, nos levando para o rapsodismo da Antiguidade (Egito, Grécia) e nos aproximando dos processos lírico-discursivos dos sacerdotes indianos e cantadores ambulantes russos, nos dão elementos formalísticos e expressivos para a criação da melodia infinita caracteristicamente nacional. (ANDRADE, 1964, p. 64).

Amaro Cavalcanti de Albuquerque (1969, p. 95) analisou a influência da tradição popular típica de uma comunidade na execução de hinos, orações cantadas e salmos que acompanham a liturgia religiosa, música que absorveu da cultura oral "[...] a liberdade de forma e melodia infinita, como nos fandangos paulistas, nos martelos, parlendas, pregões, rezas de macumba, etc." Tal influência apresenta variáveis particulares, conforme o momento histórico e o perfil geopolítico do espaço em que se manifesta, a exemplo das políticas nacionalistas europeizantes do século XIX, sobre as quais afirmou José Miguel Wisnik (1982, p. 164): “[...] o nacionalismo folclorizante (...) quer sinfonizar a totalidade social trazendo para a moldura do concerto a música dos espaços populares recalcados e submersos (as danças dramáticas, os cocos, os pregões, as rodas infantis, etc)".

Sobre a influência europeizante no espaço público, Maria Inez Machado Borges Pinto (1994, p. 161) observou: "Muitos destes vendedores ambulantes de miudezas e petiscos, estrangeiros, serviam-se dos atrativos exercidos pela sua diferença cultural, sobretudo da língua, das canções, usando-as como recursos para atrair a clientela.” 


\section{Pregões e vendedores de rua em Baú de Ossos}

Publicadas em 1957, as crônicas do memorialista da capital paulista, Jorge Americano reconstituem o cotidiano das ruas de São Paulo de várias formas, incluindo referências aos sons: "O vaivém da serra manual da serraria do outro quarteirão e o canto da cigarra, o assobio do afiador de facas, uma porção de pregões na rua e o canto da lavadeira batendo a roupa”, espécie de arquivo sonoro que complementa a descrição das idiossincrasias dos pregões anunciados pelos vendedores ambulantes, como um atrativo:

Ouve-se um assobio e o pregão: "Amolador!" (...) Ouve-se ao longe um pregão fanhoso que não se entende. Não se percebe ao longe ninguém que tenha aspecto de apregoar qualquer coisa. O som se aproxima: "Empalhador!" "Empalhador!" O homem não se distingue dos outros. Ah! Agora distingue-se. Traz na mão um feixe de palhinha de vime. (...) Ouve-se um grito estridente. Este pregoeiro fala francês: "Fraternité, Égalité, 'vassourité', la facilité de la famille." Não é francês, não sabe francês, mas era o vassoureiro preferido, porque the ensinaram aquelas imbecilidades. (AMERICANO, 2004, p. 105112).

Sobre os vendedores ambulantes das ruas de Recife, afirmou Alceu Maynard de Araújo (1973, p. 32): "Já estão se tornando, pela raridade, tipos folclóricos, os vendedores das ruas do Recife, com seus pregões anunciadores das mercadorias que vendem.” Alguns ambulantes da cidade de São Paulo surgem como "tipos folclóricos" em Memória e sociedade: lembranças de velhos (1979), de Ecléa Bosi. O depoimento do Sr. Antônio, descendente de italianos de Ortanuova, província de Foggia, nascido em 1904, em Santa Rita do Passa Quatro, descreve pregões do bairro do Bexiga e seus arredores em 1910:

Um argentino elegante, bem falante, passava pelas ruas do centro da cidade, fazendo propaganda de cigarros: "Pierrot 64!". Pelos bairros passava um foggiano que vendia dez laranjas por um tostão. (...) O pasteleiro vendia assim dois pastéis quentes por um tostão: a dois cem réis pas téis a dois cem réis pas téis. O pipoqueiro mulato tinha vindo da construção da Alta Sorocabana (diziam que levavam os mulatos para lá parque as onças preferiam os mulatos para comer). (...) O calabrês vendia pimenta: "Ó pimenta". Um sorveteiro de Foggia gritava: "Surveta! Surveta!". Tinha um que era sargento da Força, também italiano: "A tostón o pedaço! Melanzia barata! / Come, bebe e lava a cara”. O sorveteiro vinha de longe gritando fininho: "Zzzzzzurviete!”. Vinha um, com um animal, e vendia sapato, chinelo, tudo (...) $O$ vassoureiro era célebre em São Paulo com seu pregão em francês que não lembro mais. Tinha o pai do Salerno, colega meu do grupo escolar: Outro, que era acendedor de lampiões da Companhia de Gás (naquele tempo São Paulo era iluminada a gás), vendia espigas quentes, e diziam que virava lobisomem: "Ei, espiga cávida!” (...) Cada bairro tinha seus apregoadores. (BOSI, 1979, p. 229-231, grifo da autora).

A pesquisa do historiador Isaac Grinberg sobre o município de Mogi das Cruzes, no interior do estado de São Paulo, envolveu décadas de investigação e resultou na publicação de onze livros. Em Mogi das Cruzes do meu tempo (1920 a 1950), Grinberg (1993, 118) descreveu o 
"pregão (canto dos vendedores ambulantes)" e os produtos que também se faziam anunciar "pelo som de instrumentos (como gaita, por exemplo, ou campainhas ou buzinas ou apitos (...). A pé, de bicicleta, de carroça, com carrocinha ou carrinho”. O trabalho e testemunho do autor são fontes que interessam aos estudos culturais, historiografia, sociologia e antropologia das emoções, neste caso, ao relacionar o foco das investigações à vida afetiva no cotidiano, por exemplo, quando observa como o vendedor ambulante "[...] se tornava velho conhecido de sua freguesia, especialmente das crianças e muitas vezes era até aguardado com ansiedade”. Dados importantes e detalhados reconstituem costumes, expressões e labores praticamente extintos:

Havia muitos vendedores pelas ruas, geralmente reconhecidos à distância, seja pelo pregão (canto dos vendedores ambulantes) ou pelo som de instrumentos (como gaita, por exemplo, ou campainhas ou buzinas ou apitos (...) Vendedor de palmito fresco, em lombo de burro; vendedor de lenha, em carro de boi; vendedor de lenha em mucuta (maço de lenha fina, amarrada com cipó); vendedor de pé de moleque em cesta coberta com pano de saco de farinha de trigo. Vendedor de paçoca, em saquinho de papel manilha com formato de cone; vendedor de batata doce assada, em cesta coberta com pano grosso para não esfriar. Pregão: - "Batata assada u forno..." Vendedor de biscoito de polvilho, em grandes cestas cobertas com pano branco; vendedor de pastéis. Pregão: "Guá-pastéis"; vendedor de bagres, em fieira de cipó; vendedor de leite de cabra. Andava com meia dúzia de cabras pelas ruas e tirava o leite em copo, com açúcar, na porta da casa do comprador (GRINBERG, 1993, p. 118-119).

Ao biografar os avós paternos, Pedro da Silva Nava e Dona Ana Cândida Pamplona da Silva Nava, o memorialista apresenta um panorama do centro comercial do Rio de Janeiro, entre 1878 e 1880, em que ambulantes se misturam ao tipos humanos:

Esses caminhos cortavam o centro urbano, esse encontro vivo e característico das ruas da freguesia do Sacramento, Santa Rita e Candelária, cheio de teatros como o Alcazar da Uruguaiana, das redações dos jornais da mesma rua e da Gonçalves Dias, de prostíbulos como o Palácio de Cristal, do canto da última com Rosário. Neles passava meu avô, acotovelando-se com políticos, portugueses, escravos, marinheiros, barões, crioulas, capoeiras, generais, jornalistas, doceiras, colegiais, quitandeiros, senhoras, fotógrafos, peixeiros e prostitutas; desviando-se dos carris, das vitórias, gôndolas, tílburis, landaus, aranhas, caleches, berlindas e burros sem rabo que atropelavam desordenadamente o solo escorregadio das imundícies, das cascas de frutas, detritos alimentares, baganas, escarros e cusparadas; respirando o cheiro especial do velho centro do Rio de Janeiro - misto de exalações de frutas frescas e frutas podres, da bosta dos estábulos, dos moinhos de café, das barracas de peixe, dos montes de lixo, de leite azedo, de queijo ardido, dos mercados de flores, do perfume das senhoras que passavam rangendo sedas machadeanas Fidélias, Capitolinas e Virgílias! E do bodum da pretalhada carregando fardos; ouvindo as conversas, os assovios, as cantigas e as obscenidades de uma população que xingava, praguejava e dizia safadezas com o mesmo gosto com que cuspia de esguicho. No meio desse fervilhar de vida passava meu avô para chegar à sua Rua de Gonçalo Gonçalves. (NAVA, 1974, p. 69-70, grifo do autor).

Tal descrição encontra correlativo poético na recriação da rotina do sobrado familiar da 
Rua Aristides Lobo, no Rio de Janeiro. Nava utiliza uma linguagem repleta de sugestões sinestésicas, alusivas a cores, aromas e sons, que ora margeia a poesia simbolista, ora a estética realista, ora o relato do historiador e do cronista dos costumes:

[...] emergem as figuras da rua e os sons que as circundavam. Desde cedo. Ainda escuro, de madrugada. $O$ primeiro a entrar na sinfonia era aquele apito de fábrica - ainda destituído de seu conteúdo futuro. Logo depois vinham vindo os próprios pregões. $\mathrm{O}$ áspero e gritado dos peixeiros, alongando o seu peiiiiiiiixcamaró, entrando de portão adentro e indo até a escada da cozinha onde descansavam as pesadas cestas pendentes do varapau que lhes esmagava os ombros e que eles seguravam dos lados, como em gravura chinesa. Subia das cestas um relento oceânico e a faiscação de estanho e prata suja dos peixes (...) Obrigada, freguês! Obrigado, freguesa! O lusíada cordial forrava o lombo com a toalha grossa, recarregava-se e ia soltar na rua seu silvo de locomotiva. Como um clarim, chamando. Respondiam-lhe sons de buzina graves e roucos, sons que tremiam, não apenas no ouvido, mas fazendo vibrar o tambor da barriga e que tinham curiosa analogia com o cheiro e a aparência cruel das vísceras que o fissureiro anunciava com aquele toque solene e funerário. Os fígados lisos e cor de vinho, as tripas douradas e lustrosas, miolos duma brancura de estearina, mocotós de marfim, os corações roxos como mangará de cacho de banana. Os rins. Gentileza de tripeiro: os bofes, feito uma gelatina cinzenta e rosada que ele trazia para o banquete dos cachorros que sucedia ao dos gatos, antes cevados a guelra de peixe. $\mathrm{O}$ carrasco de mãos sangrentas levava à boca sua trompa de chifre e saía, numa nuvem de moscas e de apelos lancinantes e plenos como os das fanfarras em torno dos cadafalsos. Logo depois passava gritando outro verdugo. Rato, rato, rato! Corria de dentro das casas o tropel das mulatas, meninos, patroas, moleques e crioulas com suas ratoeiras e todos despejavam o conteúdo das armadilhas dentro de uma espécie de sorveteira enorme que continha um líquido que dava fumaça sem ferver. (...) $\mathrm{O}$ homem, em vez de receber, pagava. Duzentos réis a ratazana, um tostão por camundongo. Pagava, tampava, punha na cabeça e seguia soltando o pregão que virou música do rato, rato, rato, / camundongo, percevejo, carrapato - que ficamos devendo ao empresário da compra que era o Dr. Oswaldo Gonçalves Cruz. (NAVA, 1974, p. 311-312, grifo do autor).

Nava (1974, p. 353) demonstrou talento precoce para o desenho. O caderno "de capa alaranjada”, presente do tio, o escritor Antônio Salles, é o segundo objeto "já tocado pelo tempo e recomeçando a representar o passado" citado entre as recordações marcantes da meninice: "Quando ele reapareceu, fui aproveitando suas páginas em branco para novos desenhos que se superpuseram aos antigos como as camadas sucessivas de Tróia e onde só eu, Schliemann! - distingo o que é 1910, 1911, 1914 e 1918 (...) bocado tangível de minha infância.” O aspecto arqueológico do caderno de Nava (1974, p. 354) distingue-se conforme a noção de traço de Boursier: "Foi folheado por dezenas de mãos agora mortas, cujo suor vivo e cujas impressões digitais deixaram nele - para sempre! - seu traço.” Nos anos vinte, as caricaturas, esboços e pinturas de Nava receberam elogios de integrantes do Modernismo. Esta inclinação para o belo preenche a linguagem das Memórias, como atesta a primeira parte deste excerto, evocação proustiana do estilo de integrar às cenas e perfis psicológicos menções às artes plásticas, à música e pintura. $\mathrm{O}$ trecho alude à musicalidade dos pregoeiros que, segundo 
Tinhorão (2005, p. 59), "muitas vezes" surge do modo de ressaltar a entoação das sílabas de uma palavra, "[...] de forma sonora, compassada e bem escandida - como o famoso grito dos portugueses compradores de garrafas vazias do Rio de Janeiro: 'ga...rrra...fei...ro-o-o-o...' - o pregão revela uma tendência inapelável para transformar-se em música”, sobretudo quando o pregão explora as modulações da voz, "cantando em bom sentido os nomes dos artigos que tem para vender ou que deseja comprar”. A descrição a seguir, a linguagem é similar à do historiador da arte. A ideia do canto para amenizar o trabalho também é presente:

Mas já a aquarela da manhã ia dando lugar aos tons mais firmes do óleo do meio-dia e, de acordo com o ouro mais forte e o azul mais apanhado da hora, surgiam os vassoureiros e doceiros. Aqueles anunciavam sua mercadoria num longo canto que subia sustenido como o garganteio de uma flamenca e parece que eles próprios se deleitavam porque seu olha a baxxoiréirrr olha a baxxoirrexxxpanadoirexx era feito com a mão em concha sobre a orelha, para o tenor nada perder da sua malagueña. (NAVA, 1974, p. 312, grifo do autor).

A escrita confessional memorialística, que reúne as memórias voluntária e associativa, não se eximiria do que Diet (2010, p. 41) designou por alusões culturais explícitas e recorrentes: associações sobre um personagem, certa passagem histórica ou romanesca, a situação dramática de uma emissão televisiva, a cena de filme, uma emoção musical ou estética, a evocação de um intérprete ou uma interpretação, reminiscências de emoções estéticas e de revelações artísticas, lembranças de prazeres experimentados na descoberta e reencontro de objetos culturais. Nesta passagem, o trabalho da memória voluntária reconstitui a paisagem urbana em que se moviam os vendedores ambulantes, com produtos que dão ideia da organização doméstica, dos costumes e do paladar de uma época, alusões que a memória associativa enriquece com imagens poéticas e literárias:

Era incrivel a quantidade de vassouras curtas para chão e longas para teto, feitas de palha ou piaçava, que os homens traziam com as miúdas, de latrina; com lotes de espanadores de todos os tamanhos e de todas as cores, com as cestas para roupa suja; os abanadores de ferro de engomar, batedores de tapete e vasculhos de penas multicores que lembravam flabelos papalinos atravacando a rua e obrigando a alimária humana a manobrar como um veículo quando tinha de voltar sobre os próprios passos ou dobrar uma esquina. (...) Mas voltemos à Aristides Lobo e ao fim da hora neutra de depois do almoço - pontuada pela avena dos doceiros. Lá vinham eles do Largo do Rio Comprido... A cabeça encimada pela torcida de pano que lhes dava ares de spahis. Era sobre esse turbante que descansava a caixa dos doces, envidraçada, aos lados, como o esquife de cristal da Branca de Neve, coberta, em cima, por uma tampa forrada de oleado e tendo quatro pés, como mesa, para a hora comovente da escolha entre as brevidades desérticas, os úmidos quindins, as cocadas brancas e pardas - conforme feitas com açúcar refinado ou rapadura. Os doces de batata roxa, batata comum, de abóbora, de cidra, de mamão ralado. Os pés-de-moleque de amendoim inteiro ou pilado, de massa açucarada como vidro ou ressecada como um reboco. Ao levantar-se a tampa, vinha aquele cheiro envolvente e sedativo, onde as narinas surpreendiam tonalidades altas do odor do limão e da laranja; as claras, do leite, do coco, das farinhas; as baixas e mais surdas do ovo, do cravo, da baunilha, do melaço. 
Eram cromáticas como as cascatas de sons que o doceiro tirava do instrumento com que se anunciava. Não se tratava de simples flauta, mas de vários tubos - do sírinx polícano de Pan que vinha dar à Rua Aristides Lobo ressonâncias antigas e pagãs. $\mathrm{O}$ sopro retilíneo e adestrado tirava dos tubos sucessivos escalas que vibrava argentinamente, que faziam tremer o metal susceptível dos gradis prateados que eu segurava e a ondulação sonora e táctil entrava pelos meus ouvidos, pelas minhas mãos, enchendo a minha boca da água da antecipação do gosto. (NAVA, 1974, p. 312-313).

"Diante da diversidade e do barulho dos pregões dos escravos do Rio de Janeiro, Ewbank chegou a dizer que os pregões de Londres eram 'ridicularias comparados aos da capital brasileira”" (SOARES, 2007, p. 126), diversidade que parece ter sido preservada até o início do século XX, conforme está registrado em Baú de Ossos. Pedro Nava ressalta a impressão causada pelo aspecto sonoro, a musicalidade e o gestual dessa performance:

Outros vendedores ambulantes, com outros barulhos. Baleiros - baleiro-bááála - pulando dos estribos dos bondes que subiam para os passeios e destes, tornando a levitar-se, com seu grito, para os que desciam - realizando o milagre de equilibrar e manter arrumadas as bandejas com os pacotes de biscoitos Brichy; com os peixes, as moedas, os cigarros, os charutos e os cachimbos de chocolate envoltos em lâminas de ouro, prata e púrpura; os enrolados de balas, feitos de papel brilhante e lustroso em que uma rodela de cor indicava a qualidade. (...) Dilim-dilim era o nome onomatopaico dado a um cartucho de massa de trigo que se quebrava nos dentes e derretia na língua feito hóstia. Vinham uns enfiados nos outros e seus cones se arrumavam espiralados numa enorme lata redonda que o ambulante trazia às costas, segura por bandoleira para, com as mãos livres, percutir o triângulo de metal que fazia dilim-dilim, dilim-dilim, dilim-dilim... Esse ruído casava-se ao rufo brioso e ovante, tirado com varetas, do baú de folha-de-flandres que os vendedores de puxa-puxa traziam na cabeça. Azuis ou cor-de-rosa, eram escrínios cheios de joias completamente brancas, do coco e do açúcar, ou tendo riscos de anilina sobre sua opalescência. Juntava-se aos dois ruídos o estalar de matraca dado pela batida rápida de um arco de ferro articulado sobre madeira e acionado por pronações e supinações velocíssimas do braço do homem do algodão. Algodão de açúcar, centrifugado na máquina que o fabricava, como estratos, nimbos, cirros e depois cumulus que viravam naquele caldo de chuva, dentro da boca. Já tinha anoitecido e já era depois do jantar quando irrompiam da treva quente os gritos dos sorveteiros. Sorvetêêet'iáiá. Creme, coco, abacaxi. (NAVA, 1974, p. 313-314, grifo do autor). 


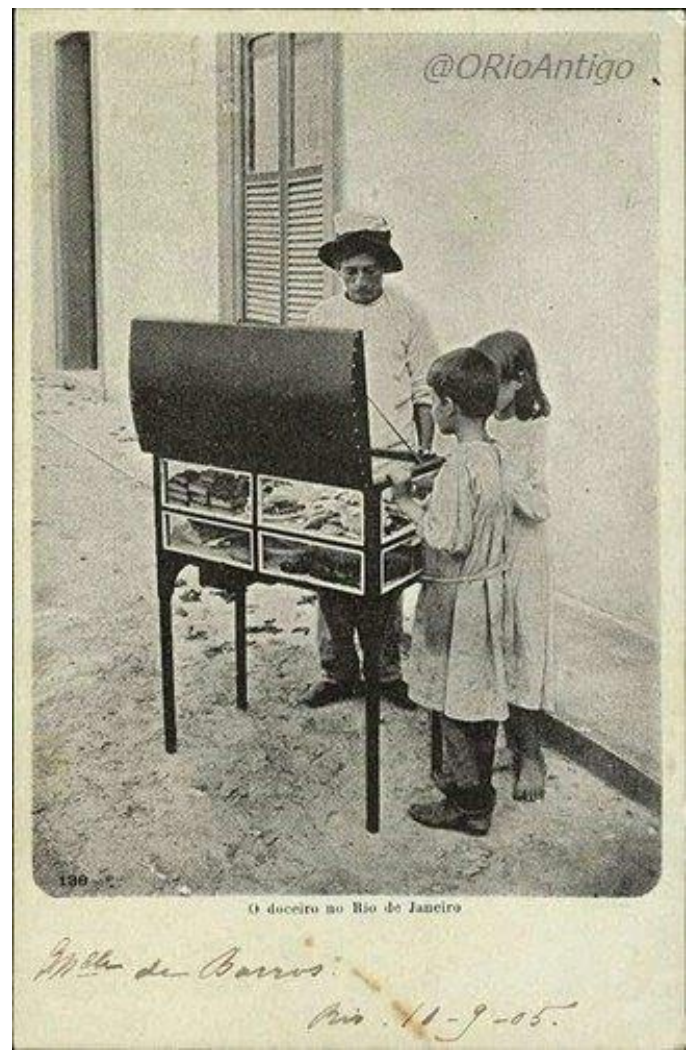

Figura 2- O doceiro, Rio de Janeiro, 1905, por Marc Ferrez.

Retirada de: Rio Antigo.

Disponivel em: <https://threader.app/thread/631227314823647233 >Acesso em: 15 de out. de 2019.

A presença dos vendedores ambulantes e respectivos pregões aparece em Baú de Ossos como reminiscência do mundo infantil. Concernente às memórias de infância, a referência ao objeto cultural não é apenas signo do investimento de sentido que ele porta e evoca, afirmou Diet (2010, p. 42), mas, como forma e conteúdo, a mesma referência pode conter diferentes valores, segundo os momentos e modalidades de elaboração, valor ilustrativo ou interpretativo na cadeia associativa de uma passagem biográfica. Porém,

As poucas notícias sobre a existência de pregões nos principais centros urbanos brasileiros encontram-se não em livros de folclore ou de música, mas na prosa sempre descomprometida de cronistas que, ao passassem em revista antigas impressões de suas cidades, encontram ecoando, no fundo da memória, os gritos musicais dos vendedores de rua ouvidos na infância. (TINHORÃO, 2005, p. 59).

Ao discutir a relação entre memória e história implícita no trabalho do historiador que recorre à fontes orais e documentais, Robert Vosloo (2017, p. 31) destacou dois polos da memória: sua vulnerabilidade e capacidade. $O$ estudo da memória coletiva aponta para a importância de evidenciar a realidade do passado histórico por meio de cuidadosas operações historiográficas. O trabalho da cultura como formação (Bildung) apoia-se na realidade material, histórica e factual de coisas e símbolos que estruturam um grupo de pertencimento primário, alcançando, em seguida, grupos secundários, pelos quais as pessoas constroem sua identidade e pensamento (DIET, 2010, p. 41-42). Assim, em Baú de Ossos, a menção a vendedores ambulantes 
e pregões, na acepção de objetos culturais, expande-se, das recordações de infância do autor à busca de reconstituição do ambiente, atmosfera, ruas e casas, sobretudo do Rio de Janeiro da primeira década do século XX.

\section{Considerações finais}

A memorialística é gênero multiforme, que apreende e exercita inúmeros discursos. No caso de Pedro Nava, a recriação do passado envolve fontes de primeira e segunda mão, orais e documentais, desde o complexo acervo do arquivo familiar, com cartas, diários, inventários, jornais íntimos, fotografias, gravuras, livros de "deve e haver", recortes de jornais e revistas, testamentos, a testemunhos orais, diretos ou preservados por gerações no círculo familiar, que se ramifica de diversas maneiras, estendendo-se aos amigos, criados e frequentadores da casa, a exemplo dos médicos que assistiram a família. A essas fontes vem se juntar a pesquisa bibliográfica do leitor culto, do estudioso da genealogia, do "arquivista familiar" e pesquisador da história nacional.

A reconstituição da arquitetura e rotina (incluindo a doçaria) do antigo Convento da Ajuda, "primeiro convento de religiosas que existiu no Brasil" no Rio de Janeiro, patrimônio valioso demolido em 1911, sugere extensa pesquisa de fontes históricas, literárias e pictóricas: "A litografia de Bertichem mostra o que eram suas proporções a um tempo simples e majestosas (...) Também as compotas, suas marmeladas - de que Machado de Assis dá notícia nas Memórias Póstumas de Brás Cubas" (NAVA, 1974, p. 159-160). Reunidos os instrumentos de pesquisa do historiador ao olhar atento e perspicaz do cronista de costumes, Nava (1974, p. 25) ilumina cenas e perfis biográficos com uma prosa de ritmo suave, melhor descrita com as palavras escolhidas por ele para definir a escrita de seu avô homônimo: "Contando estas coisas (...) usa estilo epistolar correntio e decente - que não descamba um instante, em frase enfeitada ou veleidade literária”. A herança proustiana em sua escrita denota-se na escolha de referências a objetos artísticos que se aproximem com honestidade da imagem que pretende reproduzir.

O conceito de "lugares da memória" elaborado por Pierre Nora (1989), figura em Baú de Ossos vinculando pregões e vendedores de rua a planos confluentes: memória coletiva, memória pessoal e historiografia. A primeira relaciona-se ao que Nora (1989, p. 5) denominou memória real, comum e inviolável, remanescente de sociedades arcaicas.

A memória individual possui diversas formas de dialogar com a memória social e com a história que, na sociedade moderna é propelida a novas interpretações e representações do passado, operações mediadas por vestígios materiais e imateriais chamados de "traços" por JeanYves Boursier (2002). Em Baú de Ossos, Nava procura extrair das memórias de infância traços que tornem mais vívida a descrição dos pregões e vendedores ambulantes, evocando sabores, sons, perfumes, percursos, gestos e particularidades de variados artefatos, lembrados de acordo com seu significado e função em um momento histórico específico, como a campanha de Oswaldo Cruz contra o surto de peste bubônica no Rio de Janeiro, ou em descrições que recordam o olhar de Debret:

Mas já acabava o domingo, nas ruas escurecidas, que o gás de iluminação ia 
fazer virar num mundo verde e submarino. As visitas saíam uma por uma, demandando suas ruas da zona norte, onde havia restos de dobrados das retretas dominicais, farrapos de bandeiras de papel de seda, como numa permanente festa junina e vendedores dos roletes de cana passados num barbante. Iam e vinham cantando. Óoooooolha a cana, cana doce. Os parentes iam sendo levados procissionalmente ao portão. (NAVA, 1974, p. 335, grifo do autor).

Emmanuel Diet (2010, p. 42) adverte que a leitura do pesquisador não deve negligenciar a importância da evocação de um objeto cultural, obra e saber surgidos como traços de recordações que funcionam como exercícios de representação e interpretação do passado. Pregões e vendedores de rua, avaliados como objetos culturais no contexto social do Rio de Janeiro, entre o final do século XIX, período relativo à reconstituição das ruas da cidade na passagem biográfica sobre Pedro da Silva Nava, avô do memorialista, e início do século XX, época da infância do autor, aparecem na descrição do quadro de costumes envoltos por uma linguagem poética. Nesse sentido, a memorialística contribuiria para lançar luz sobre o estudo histórico e a crítica literária.

\section{Referências}

ALBUQUERQUE, C. A. C. Música brasileira na liturgia: subsídios para o problema. Petrópolis: Editora Vozes, 1969.

ANDRADE, M. Obras completas: ensaios sobre a música brasileira. Vol. 6. São Paulo: Livraria Martins, 1964.

AMERICANO, J. São Paulo naquele tempo (1895-19015). São Paulo: Carrenho, 2004.

ARAÚJO, A. M. Áreas culturais. São Paulo: Editora Brusco, 1973.

ASSIS, M. Dom Casmurro. São Paulo: Abril Cultural, 1978.

BOSI, E. Memória e sociedade: lembranças de velhos. São Paulo: Companhia das Letras, 1995.

CANDIDO, A. Poesia e ficção na autobiografia. In: A Educação pela Noite e Outros Ensaios. São Paulo: Editora Ática, 1987.

DIET, E. Lóbjet culturel et ses fonctions médiatrices. Connexions, Paris, n. 93, p. 39-60, 2010. Disponível em: <https://www.cairn.info/article.php?ID_ARTICLE=CNX_093_0039\#>Acesso em: 05/10/2019.

GRINBERG, I. Mogi das Cruzes do meu tempo (de 1920 a 1950). São Paulo: Lis Gráfica e Editora, 1993.

MAIOR, M. S. Recife: a riqueza de seu folclore. Mario Souto Maior vida $E^{2}$ obra, s/d. Disponível em:

$<$ http://www.soutomaior.eti.br/index.php?option=com_content\&view=article\&id=53\&Itemid =13> Acesso em: 08/10/2019.

NAVA, P. Baú de Ossos. Rio de Janeiro: Livraria José Olympio, 1974.

PINTO, M. J. B. Cotidiano e sobrevivência: a vida do trabalhador pobre na cidade de São Paulo, 
1890-1914. São Paulo: Edusp, 1994.

RICOEUR, P. La Mémoire, l'Histoire, l’Oubli. Paris: Seuil, 2000.

SOARES, L. C. O "povo de cam" na capital do Brasil: a escravidão urbana no Rio de Janeiro do Século XIX. Rio de Janeiro: Faperj - 7 Letras, 2007.

VASCONCELOS, E. De bissexto a contumaz. In: Inventário do Arquivo Pedro Nava. Ministério da Cultura. Fundação Casa de Rui Barbosa. Arquivo-Museu de Literatura Brasileira. Rio de Janeiro: Edições Casa de Rui Barbosa, 2001, p. 9-32. Disponível em:

<www.casaruibarbosa.gov.br/pedronava/downloads/inventarionava.pdf>. Acesso em: $11 / 10 / 2019$.

VOSLOO, R. Reforming Memory: Essays on South African Church and Theological History. Stellenbosch: African SunMedia, 2017.

TINHORÃO, J. R. Os sons que vêm da rua. São Paulo: Editora 34, 2005.

Recebido em: 28/10/2019

Aceito em: 10/01/2020 